\title{
25 Research Soure \\ Why Did They Fail? A Case Study on Undergraduate First Year Medical Students
}

Research article

Keywords:

Posted Date: March 16th, 2021

DOI: https://doi.org/10.21203/rs.2.18779/v3

License: (c) (i) This work is licensed under a Creative Commons Attribution 4.0 International License.

Read Full License 


\section{Abstract}

The authors have requested that this preprint be withdrawn due to erroneous posting.

\section{Full Text}

The authors have withdrawn this preprint from Research Square. 